\title{
European political cooperation (EPC)
}

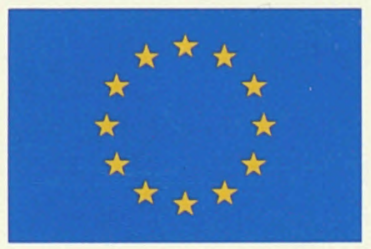


$$
\cdot
$$ 


\section{European \\ political cooperation (EPC)}


Text completed in April 1988

Luxembourg: Office for Official Publications of the European Communities, 1988

Catalogue number: FX-52-88-574-EN-C

(C) ECSC-EEC-EAEC, Brussels · Luxembourg, 1988

Reproduction is authorized, except for commercial purposes, provided the source is acknowledged.

Printed in the Federal Republic of Germany 


\section{Contents}

Introduction $\quad 5$

$\begin{array}{ll}\text { Structure and organization } & 6\end{array}$

The Presidency 6

$\begin{array}{ll}\text { Relations with the European Communities } & 7\end{array}$

Relations with the European Parliament 7

$\begin{array}{ll}\text { Cooperation in international fora } & 8\end{array}$

$\begin{array}{ll}\text { Cooperation in third countries } & 8\end{array}$

What subjects does EPC cover? 9

$\begin{array}{ll}\text { What does EPC achieve? } & 13\end{array}$ 


\section{Introduction}

$\square$ uropean Political Cooperation (EPC) is the process of information, consultation and common action among the 12 Member

States of the European Community ('the Twelve') in the field of foreign policy. Its aim is to maximize the Twelve's influence in international affairs through a single coherent European approach. It is the essential counterpart to progress towards European unity in the Community framework.

EPC is not static, but a process which continues to develop and evolve. Its origins go back to the 1950s, when cooperation on foreign policy was seen as an integral part of building a new Europe after the war, a Europe which could speak with a single voice to the rest of the world. But it was only in 1970, when Foreign Ministers approved the 'Luxembourg Report', that the basic procedures of EPC were established. Since then the process of cooperation has gradually been developed, expanded and formalized in a number of stages, culminating in the entry into force of the Single European Act on 1 July 1987. The Single Act puts EPC on a Treaty basis for the first time, although it remains quite distinct from the structures and procedures of the Community.

The key features of EPC are:

$\square$ a commitment to consult and cooperate on foreign policy issues and to work towards coordinated positions and joint actions;

$\square$ a commitment to consult before adopting national positions on foreign policy issues of general interest;

$\square$ decision-making by consensus among governments;

$\square$ the confidentiality of consultations;

$\square$ direct contacts between Foreign Ministries, allowing speed and flexibility;

$\square$ only two working languages (English and French) at meetings below Ministerial level. 


\section{Structure and organization}

$\square$ European Council (Heads of State or Government; Foreign Ministers; the Commission): one meeting per Presidency, covering both EC and EPC subjects.

Foreign Ministers: At least two EPC meetings per Presidency, plus one informal weekend (emergency Ministerial meetings can be called at 48 hours notice). EPC subjects are also frequently discussed by Ministers in the margin of EC Council meetings.

$\square$ The Political Committee (senior Foreign Ministry officials): manages the day-to-day business of EPC, acts as a clearing-house for routine decisions and prepares Ministers' discussions. Regular monthly meetings, plus emergency meetings if required.

$\square$ The Group of European Correspondents (one of ficial from each country's Foreign Ministry): monitors the smooth functioning of EPC.

$\square$ Working Groups (15-20 groups in all): regular meetings at expert level - on average each Group meets two or three times per Presidency.

EPC also involves cooperation among representatives of the Twelve in third countries and to international organizations.

\section{The Presidency}

7 he country holding the Presidency of the EC Council (which changes every six months) is also in charge of EPC. The Presiden-

1 cy's functions within EPC include:

$\square$ arranging and chairing meetings;

$\square$ setting agendas;

$\square$ proposing joint actions;

$\square$ drafting common statements;

$\square$ acting as the Twelve's spokesman in international fora and in meetings with third countries;

$\square$ representing the Twelve in relations with the European Parliament. 
Since the beginning of 1987 the Presidency has been assisted by a small Secretariat, based in Brussels. This is made up of the Head of the Secretariat, appointed by Ministers, and five officials seconded from Foreign Ministries, on a rotation basis, plus support staff. It helps to reduce the administrative burden on successive Presidencies and to ensure continuity. EPC meetings are held either in the Presidency capital or in the Secretariat.

The 12 Foreign Ministries, the Commission and the EPC Secretariat are linked by a confidential telex ('Coreu') which provides rapid and secure communications at all times. This network allows the Twelve to exchange views and information and to decide on action, especially in cases of urgency, without holding special meetings.

\section{Relations with the European Communities}

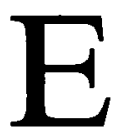

PC is not based on the Treaties establishing the European Communities and it has a quite separate institutional structure. However, EPC and the Communities together form an integral part of the European identity projected to the outside world. It is clearly essential that the policies developed in EPC and the external policies of the Communities should be consistent and therefore mutually supportive. EPC and Communities' policies are thus placed within a coherent political vision.

The Commission is fully associated with EPC and is represented at all EPC meetings.

\section{Relations with the European Parliament}

7 he European Parliament is closely associated with EPC. The Presidency regularly informs the Parliament about subjects discussed

1 in EPC and ensures that the Parliament's views are taken into account by EPC. Specifically: 
$\square$ the Presidency Foreign Minister makes a speech in the Parliament at the beginning and end of his period in office;

$\square$ the Presidency attends a monthly Question Time in Strasbourg and coordinates joint answers to questions from Members of the European Parliament;

each Presidency takes part in two 'colloquies' (informal and confidential discussions) with the Parliament's Political Affairs Committee.

\section{Cooperation in international fora}

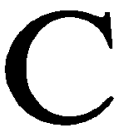

ooperation in international fora is an important aspect of EPC. This is particularly true of cooperation in the CSCE framework (see page 9) and the United Nations, which includes:

regular consultations between the Twelve's missions in New York, Geneva and Vienna, including at expert level;

an annual speech by the Foreign Minister of the Presidency in the name of the Twelve and the Community at the UN General Assembly;

endeavours to secure common voting on Resolutions;

$\square$ joint statements and common explanations of vote.

\section{Cooperation in third countries}

7 he Twelve's missions in third countries cooperate closely both on political questions and on other issues. Ambassadors have regular 1 meetings, often inviting prominent figures such as their host Foreign Ministers to attend. They draft joint reports, recommend common policies and undertake joint actions in the name of the Twelve (e.g. démarches on human rights). Usually the Presidency acts on behalf of the Twelve in such cases, but sometimes the so-called Troika - involving the preceding, present and succeeding Presidencies, plus the Commission is used in order to emphasize the Twelve's common approach.

In many capitals regular meetings take place between consular, commercial and administrative specialists. Areas of practical cooperation include 
health, schooling, consular and legal assistance. In certain countries cooperation on emergency communications and emergency evacuation plans helps ensure that dangers to EC citizens living or travelling in third countries are kept to a minimum. Cooperation on the evacuation of EC citizens from Aden (South Yemen) in 1986 was a good example of this.

Overall, the Twelve's missions put across to foreign governments and to the media in third countries the reality of European cooperation on a dayto-day basis.

\title{
What subjects does EPC cover?
}

\begin{abstract}
All foreign policy issues of general interest are discussed in EPC, particularly those of direct concern to Europe. Issues under discussion include:
\end{abstract}

East/West relations and the CSCE process

These central questions, of vital importance to all Europeans, are almost permanently on the EPC agenda. The Twelve are committed to strengthening stability and security in Europe at lower levels of armaments and to enhancing mutual trust and understanding. The Twelve discuss every aspect of East/West relations, including the wider issues of security policy, but military and defence questions are not discussed in EPC (these are matters for other fora such as NATO and the WEU)

The Twelve have played a key role in the CSCE process, including in the negotiations leading to the Helsinki Final Act. Their delegations coordinated closely at the follow-up meetings in Belgrade and Madrid, as well as in meetings on specific aspects of the CSCE process. At the CSCE followup meeting in Vienna the Twelve, with other Western countries, have submitted important proposals notably on the human dimension. These are designed to allow all the citizens of Europe to benefit from the commitments made at Helsinki. 


\section{$\square$ MIDDLE EAST}

The Twelve have for many years followed developments in the Middle East closely and in particular the Arab/Israeli dispute. They have consistently supported a peaceful solution to this dispute based on two fundamental principles, which were outlined in the 1980 Venice Declaration and subsequent statements: the right of all States in the region, including Israel, to exist within secure frontiers; and the right of the Palestinian people to self-determination, with all that this implies. The Twelve believe an International Peace Conference on the Middle East would provide the suitable framework for negotiations between those directly concerned.

The European Community provides aid and economic assistance to the territories occupied by Israel since 1967. The Twelve have developed their relations with the Arab countries through the Euro-Arab Dialogue.

The Twelve are committed to UN efforts to bring about an early negotiated settlement to the Iraq/Iran conflict on the basis of the full implementation of Security Council Resolution 598. They are particularly concerned by the danger of the conflict spreading and by the threat posed to freedom of navigation in the Gulf.

\section{$\square$ SOUTH AFRICA}

The Twelve are committed to contributing actively to the total dismantling of apartheid by peaceful means and its replacement by a genuinely democratic, non-racial system of government in South Africa. The Twelve have outlined the steps which the South African Government should take to allow the necessary national dialogue to start: in particular the state of emergency must be lifted, all political prisoners freed and the ban on political parties lifted.

To support this policy, the Twelve have introduced a Code of Conduct for EC companies operating in South Africa, designed to ensure that EC companies lead the way in abolishing apartheid from the workplace and improving wages and conditions for black workers. 
Member States and the Community provide considerable aid to those who suffer as a result of apartheid, both inside and outside South Africa. This aid is designed to strengthen the economic independence and self-sufficiency of South Africa's neighbours and to help South Africa's majority community, particularly in the field of education.

The Twelve have also introduced a series of restrictive measures designed to underline their concern, to help maintain international pressure on the South African Government and to bring home to the white community the fact that fundamental change is inevitable and that delay will only make this process more difficult.

\section{$\square$ CENTRAL AMERICA}

The Twelve support efforts to achieve a peaceful resolution of the region's conflicts on the basis of the Contadora Group's objectives. They believe that a solution must emerge from the region itself and must guarantee peace, democracy and respect for human rights, along the lines proposed in the agreement reached in Guatemala on 7 August 1987. To support the process of negotiation and reconciliation, the Twelve have established a political dialogue with the countries of Central America and the Contadora Group, which takes place annually, in principle at Ministerial level. In parallel, the European Community is providing economic assistance designed to encourage regional cooperation and integration.

\section{AFGHANISTAN}

The Twelve have repeatedly condemned the Soviet occupation of Afghanistan. They have called for the rapid and unconditional withdrawal of all Soviet troops to allow the Afghan people to decide freely their own future. They supported the UN Secretary-General's efforts to bring about an early negotiated settlement. They welcomed the conclusion of the April 1988 Geneva agreements, which represent an important step towards a solution of the Afghanistan crisis. 
$\square$ Asia (e.g. developments in Cambodia, Sri Lanka, the Philippines);

$\square$ Africa (e.g. the Horn of Africa, the Front-line States, Sudan);

$\square$ Cyprus;

$\square$ South America (e.g. developments in Chile).

\section{Other issues}

\section{$\square$ HUMAN RIGHTS}

Respect for human rights is one of the key elements in the Twelve's relations with third countries. The Twelve make every effort to promote and protect human rights and fundamental freedoms: when abuses occur, they often intervene with other governments to underline European concerns and press for full respect for human rights.

\section{$\square$ TERRORISM}

The Twelve have adopted an active policy in the fight against international terrorism. They have consistently made clear their total abhorrence of this scourge and their unwillingness to maintain normal relations with countries which are involved in supporting terrorism. They have agreed not to make any concessions under duress to terrorists or their sponsors. They have taken measures, both jointly and individually, to back up this policy and to bring home to those who use terrorism that such acts can only damage the causes which they purport to support. In their efforts to combat international terrorism, the Twelve cooperate closely both among themselves and with like-minded third countries.

\section{NON-PROLIFERATION}

The Twelve attach importance to preventing the proliferation of nuclear weapons and work closely together to this end. They strongly support both the activities of the International Atomic Energy Agency (IAEA) in 
this field and the international agreements in force designed to ensure that the trade in nuclear materials and equipment is used exclusively for peaceful purposes.

\section{Other areas of cooperation}

Ways of pooling resources to maximize the cost-effectiveness of the Twelve's Foreign Ministries; judicial cooperation; improving the services provided by embassies overseas (see page 8); coordinating protocol arrangements and procedures.

\section{What does EPC achieve?}

(i) Impact on national policy

The commitment to consult and coordinate lies at the heart of EPC. The officials responsible for developing foreign policy nationally are in close and regular contact. Consultation and cooperation with colleagues at all levels from the Twelve are now natural and instinctive. Before making decisions, individual countries take full account of the policies and interests of their European partners.

\section{(ii) At expert level}

Regular meetings of expert groups and of the Political Committee not only ensure close personal relations between members of the Foreign Ministries, but also allow the Twelve to reach a common assessment of international issues as a basis for developing joint policies. There is a similar process in third countries, where the Twelve's Embassies regularly exchange information and views on the country to which they are accredited. 
The Twelve have publicly established a joint position on most major international issues. These common positions are designed to bring out the key elements of any question and, if possible, to offer the parties to a dispute a potential area of middle ground. For example, the Venice Declaration on the Middle East, made in June 1980, established two of the principles on which any solution of the Arab/Israeli conflict must be based and those principles remain entirely valid.

The Twelve's Declaration on Human Rights of July 1986 has provided a touchstone for European policy on this issue which is increasingly in the public eye and to which the Twelve pay particular attention when considering their relations with third countries.

\section{(iv) Quiet diplomacy}

The Twelve also use their numerous contacts with third countries to pursue, on a confidential basis, the policies agreed by EPC. The most important area for such quiet diplomacy is human rights: the Twelve frequently intervene confidentially with foreign governments on humanitarian issues on occasions when public declarations are judged counterproductive.

\section{(v) Joint action}

The Twelve may also take joint action in situations where this is appropriate and realistic, and where other means have not had the desired results. In 1985 and again in 1986 the Twelve introduced measures $v i s-\grave{a}$ vis South Africa, both positive (aid to the victims of apartheid) and restrictive economic measures; following terrorist incidents measures were taken in April 1986 against Libya and in November 1986 against Syria; the Twelve's political commitment to encouraging peace and regional cooperation in Central America is reinforced by Community support for economic integration amongst the countries of the region. 
The Twelve have close links, whether informal or institutionalized, with many third countries and groups of countries. These contacts are normally the responsibility of the Presidency or, in some cases, the Troika. They cover not only other European and Western countries but also regional groupings such as Asean, the countries of Central America, the Gulf Cooperation Council and the Arab League. The Twelve are increasingly seen as a coherent entity with which third countries want to discuss foreign policy issues: this allows the Twelve's views to be heard widely and at a high level, thus maximizing the Twelve's impact on world affairs. 
- 

